\title{
Hamster Insulinoma
}

National Cancer Institute

\section{Source}

National Cancer Institute. Hamster Insulinoma. NCI Thesaurus. Code C134946.

Insulinoma that occurs in a hamster. 